\title{
Evaluation of responses to tomato brown rugose fruit virus (ToBRFV) and selection of resistant lines in Solanum habrochaites and Solanum peruvianum germplasm
}

\author{
Ahmad Jewehan ${ }^{1} \cdot$ Nida Salem $^{2} \cdot$ Zoltán Tóth $^{1} \cdot$ Pál Salamon $^{1} \cdot$ Zoltán Szabó $^{1} \mathbb{D}$
}

Received: 8 November 2021 / Accepted: 9 February 2022 / Published online: 3 March 2022

(c) The Author(s) 2022

\begin{abstract}
Reactions of plants in 173 wild tomato accessions belonging to Solanum habrochaites and S. peruvianum were studied by inoculation with a tobamovirus, tomato brown rugose fruit virus (ToBRFV). Around 10-50\% of plants in nine accessions of $S$. habrochaites and one of $S$. peruvianum were demonstrated to be highly resistant. Resistant plants showed no symptoms at $22-24^{\circ} \mathrm{C}$, and no virus could be detected in their inoculated and newly developed leaves using bioassays and RT-qPCR. ToBRFV-resistant plants were also resistant to tobacco mosaic virus and tomato mosaic virus. The susceptible wild tomatoes were infected systemically with ToBRFV showing different severity of symptoms. When resistant plants inoculated with ToBRFV were incubated in a plant growth chamber at a temperature of $33{ }^{\circ} \mathrm{C}$, they expressed mosaic and deformation symptoms, indicating that the resistance was broken at elevated temperature. However, when these plants were transferred to the greenhouse at $24^{\circ} \mathrm{C}$, their newly emerged leaves showed no symptoms, and the virus could not be detected in the new leaves. Cleft grafting was done with scions from a resistant plant of $S$. habrochaites LA1739 into ToBRFV-infected susceptible tomato rootstock. The scions became infected and showed mosaic symptoms indicating that the resistance was ineffective after grafting. Sequences comparison of Solyc08g075630 loci of nine resistant accessions showed high heterogenity. Only one resistant plant of $S$. habrochaites carried an allele almost identical to the resistance gene reported previously. All other resistant plants may have probably unknown gene(s) of resistance to ToBRFV.
\end{abstract}

Keywords $S$. habrochaites $\cdot$ S. peruvianum $\cdot$ ToBRFV $\cdot$ Resistance $\cdot$ Susceptibility

\section{Introduction}

Wild tomatoes serve as excellent model systems for both basic and applied plant research. Because of their genetic diversity, they have been utilized as the source of resistance to pathogens (Kole 2011). Resistance and tolerance to different viruses have been found in several wild tomato species, especially Solanum pimpinellifolium, S. peruvianum and S. habrochaites (syn: Lycopersicon hirsutum) (Razdan and Mattoo 2006).

Zoltán Szabó

szabo.zoltan.gen@uni-mate.hu

1 Institute of Genetics and Biotechnology, Applied Plant Genomics Group, Hungarian University of Agriculture and Life Sciences, Szent-Györgyi Albert str. 4, Gödöllő 2100, Hungary

2 Department of Plant Protection, School of Agriculture, The University of Jordan, Amman 11942, Jordan
Tobamoviruses, in particular, tobacco mosaic virus (TMV) and tomato mosaic virus (ToMV), have long been recognized as harmful pathogens of tomatoes all over the world (Adams et al. 2009). With the aim of control them, three dominant resistance genes marked $T m-1, T m-2$ and $T m-2^{2}$ have been introgressed from wild tomatoes to the cultivated $S$. lycopersicum. The Tm-1 gene, mapped on chromosome 2, is incompletely dominant originated from S. habrochaites PI 126,445 and suppresses virus replication (Fraser et al. 1980; Holmes 1954; Pelham 1972). The alleles $T m-2$ and $T m-2^{2}$ discovered in $S$. peruvianum PI 126,926 and PI 128,650 respectively are located on chromosome 9 and confer complete dominant resistance by restricting the virus movement (Alexander 1963; Laterrot and Pecaut 1969; Schroeder et al. 1967). Resistances based on the above three resistance genes have been found to be broken by mutant strains of TMV or ToMV (Betti et al. 1997; Calder and Palukaitis 1992; Meshi et al. 1989). In addition, Cirulli and Ciccarese (1975) and Fraser and 
Loughlin (1982) reported that the effectivity of resistances associated with $\mathrm{Tm}$ genes was temperature-dependent because it was broken at a high temperature $\left(28-35{ }^{\circ} \mathrm{C}\right)$.

In recent years, the appearance of tomato brown rugose fruit virus (ToBRFV), a new tobamovirus isolated first in Jordan and Israel, caused alarm because it overcame the resistances governed by the genes $T m-1, T m-2$, and $T m-2^{2}$ $\left(T m-2^{a}\right)$ under normal conditions (Luria et al. 2017; Salem et al. 2016). Like other tobamoviruses, ToBRFV has rodshaped particles of ca. $300 \times 12 \mathrm{~nm}$ in size, enclosing a single-stranded positive-sense RNA (+ ssRNA) genome of $6.4 \mathrm{~kb}$. The virions are stable, highly infectious, easily transmitted mechanically and by bumblebees (Bombus terrestris) (Levitzky et al. 2019). It is also seed transmissible and the infested seeds serve as primary source of the virus (Dombrovsky and Smith 2017). ToBRFV usually causes chlorosis, mosaic and mottling of tomato leaves and occasionally leaf narrowing. In addition, the infected fruits may show yellow or brown spots and rugosity rendering them non-marketable (Oladokun et al. 2019). Furthermore, ToBRFV became a dangerous pathogen of pepper (Capsicum annuum) (Panno et al. 2020; Salem et al. 2020).

There are many ways to prevent ToBRFV infections, such as seed treatment, sanitation, using disinfected materials, and grafting the plant on virus-resistant rootstock (Chanda et al. 2021; Davino et al. 2020; Samarah et al. 2021; Spanò et al. 2020). Nevertheless, the best way to its control would be the breeding and producing resistant varieties.

A great number of tomatoes and some of their relatives have already been screened, and resistance to ToBRFV has been demonstrated in some genotypes of S. pimpinellifolium, S. lycopersicum and S. habrochaites, S. ochrantum (Ashkenazi et al. 2020; Hamelink et al. 2019; Jewehan et al. 2021; Ykema et al. 2020). Ykema et al. (2020) published the genomic sequence of a nucleotide-binding site leucinerich repeat (NBS-LRR) protein associated with ToBRFV resistance. This gene was introgressed from $S$. habrochaites proved to be located on chromosome 8 . Moreover, Zinger et al. (2021) developed a DNA marker linked to a resistance gene. They speculated that the interaction of the $T m-1$ gene located at chromosome 2 with a locus discovered on chromosome 11 is the main cause for resistance to ToBRFV.

Overcoming the resistance genes, high stability, and fast geographical distribution rendered ToBRFV in the focus of tomato pathology and urges plant breeders and pathologists to keep searching for new resistance sources to this invasive virus. In this study, we give an account on the finding of highly resistant wild tomato plants in accessions of S. habrochaites and S. peruvianum, the behaviour of the resistance under high temperature, evaluate the resistance after grafting and analyzing molecular data on the genomic background of the resistance by DNA sequence comparison.

\section{Materials and methods}

\section{Plants and viruses}

A total of 92 accessions of $S$. habrochaites and 81 accessions of $S$. peruvianum were evaluated. S. lycopersicum GCR26-Craigella ( $\left.\mathrm{tm}-1^{\mathrm{GCR} 26}\right)$, GCR237-LA3269 ( Tm1); LA2088 (Tm-2), LA3471-Moneymaker $\left(T m-2^{2}\right)$ and Ceglédi $(\mathrm{Tm}+)$ were used as controls carrying known resistance genes. Seeds were supplied by MATE (Hungarian University of Agriculture and Life Sciences), Tomato Genetic Resources Centre (University of California, Davis) and the United States Department of Agriculture Agricultural Research Service (Beltsville, Maryland). The seeds were washed with distilled water, sterilized in calcium hydrochloride (10\%), washed five times with distilled water, germinated in sterilized wetted tissue and sowed in peat soil (Klasmann Traysubstrate) pots. The growing plants were regularly fertilized by Volldunger Linz fertilizer (NPK). Nicotiana tabacum cv. Samsun and N. glutinosa were used as diagnostic hosts.

Three tobamovirus isolates were used in this study, namely, a Jordanian ToBRFV-Tom2-Jo (GenBank acc.no. MZ323110), tobacco mosaic virus (TMV-U1) and tomato mosaic virus (ToMV-DH) from a deposit of the plant virus collection of Hungarian University of Agriculture and Life Sciences. The tobamoviruses used in the experiments were transmitted through single local lesions from $N$. glutinosa and propagated in N. tabacum cv. Samsun. Inocula were prepared by grinding the infected tobacco leaves in sterile phosphate buffer $0.01 \mathrm{M}$, pH $7.0(1: 5 \mathrm{w} / \mathrm{v})$. The sap was then filtered, and the extract was stored in $5 \mathrm{ml}$ aliquots at $-20{ }^{\circ} \mathrm{C}$.

\section{Inoculations and evaluations of resistance}

Fifteen young plants from each tomato accession at 3-4 true leaves were mechanically inoculated with ToBRFV- Tom2Jo. For this purpose, the leaves were lightly dusted with carborundum (500 mesh) and gently rubbed by a sterile glass spatula dipped in thawed virus-containing sap stored in the refrigerator. After rubbing, the leaves of inoculated plants were rinsed with distilled water. We used S. lycopersicum cv. Ceglédi and $N$. glutinosa as assay plants. The plants were grown in an insect-proof glasshouse at $24 \pm 2{ }^{\circ} \mathrm{C}$ temperature, $14 / 10 \mathrm{~h}$ photoperiod and $50-70 \%$ relative humidity.

Appearance and changing of disease symptoms in the inoculated plants were observed continuously and evaluated 40 days post-inoculation (dpi) using the disease severity index (DSI) (Table 1). DSI was calculated by the formula developed by (Camara et al. 2013): 
Table 1 Severity classes and symptoms for calculating disease severity indices

\begin{tabular}{ll}
\hline Classes & Symptoms \\
\hline 0 & No symptoms \\
1 & Mild mosaic or mottling \\
2 & Mosaic \\
3 & Mosaic and leaf deformation \\
4 & Mosaic and leaf deformation, shoestring \\
5 & Severe mosaic, leaf deformation, roll- \\
& ing, shoestring, stunting \\
\hline
\end{tabular}

$\operatorname{DSI}(\%)=\sum_{e=0}^{4} \frac{e \operatorname{Re} \times 100}{5 N}$

where DSI $=$ disease severity index; $\mathrm{e}=$ class; $\mathrm{Re}=$ number of plants in class (e); $\mathrm{N}=$ total number of plants.

Presence or absence of the virus in symptomless plants (class 0 ) was evaluated after 40 dpi by bioassay and reversetranscription quantitative polymerase chain reaction (RTqPCR). Virus-free individuals assumed to be resistant were re-inoculated with ToBRFV and assayed for the presence of the virus again. After the second inoculation, the plants that remained symptomless were decapitated to induce lateral shoots. Two weeks later, two leaves of a lateral shoot in each plant were inoculated again with ToBRFV, and another lateral shoot of each plant was cut-off and rooted in Murashige and Skoog media (MS) for four weeks. Around 10-12 plants from each rooted shoots were propagated and transferred to pots for further experiments. Three to four plants were inoculated with ToBRFV-Tom2-Jo, ToMV-DH and TMV$\mathrm{U} 1$, respectively, and were evaluated for symptoms and the presence or absence of tobamovirus using bioassays and RT-qPCR.

\section{Detection of viruses in inoculated plants}

The presence or absence of viruses was examined in the inoculated tomato leaves $10 \mathrm{dpi}$ and in the top (newly developed) leaves after 40 dpi using bioassay and RTqPCR. Before the assays, leaves were washed in $2 \% \mathrm{NaOH}$ solution and then in distilled water to avoid surface virus contamination.

Bioassays were carried out by rubbing $N$. glutinosa indicator plants with leaf extract of inoculated and top leaves of donor tomato plants. For RT-qPCR, total RNA extraction from newly developed and inoculated leaves was done using Trizol RNA isolation protocol following manufacturer's instructions (UD-GenoMed, Debrecen, Hungary). To obtain accurate results, internal control genes was used based on the primers EF $\alpha 1$ and GAPDH reported by
(Expósito-Rodríguez et al. 2008). The extracted RNA was used as a template for one-step RT-qPCR applying qPCRBIO SyGreen 1-Step Detect Kit following the manufacturer's instructions (PCR Biosystems, London, UK). The primers specific for ToBRFV, ToMV and TMV used in this work were the same as described by Jewehan et al. (2021). Amplified PCR products were identified by electrophoresis in agarose gel $2 \%$ (in $0.5 \times$ TBE buffer). The LightCycler ${ }^{\circledR}$ 96 software detection system program was used to analyze the data.

\section{Evaluation of resistance to ToBRFV under elevated temperature}

Six resistant plants of each accession propagated vegetatively on MS media, were inoculated with ToBRFV-Tom2Jo. Three inoculated plants of each accession were kept into a Sanyo environment plant growth chamber at a constant temperature of $33^{\circ} \mathrm{C}$ (day length $14 \mathrm{~h}$, light intensity $50 \mathrm{Wm}^{-2}$ ). For comparison, three sister plants were grown as a control in a greenhouse at $24 \pm 2{ }^{\circ} \mathrm{C}$. The symptomatological evaluation was carried out in the "Sanyo" population and the greenhouse population parallelly. Bioassays on $N$. glutinosa were made from each plant irrespective of the symptoms that appeared. Three weeks after inoculation, plants from the chamber were transferred to the greenhouse and kept there for weeks to analyze the symptoms and evaluate the presence of the virus in newly developed leaves.

\section{Cleft grafting}

Four weeks-old S. lycopersicum cv. Ceglédi plants infected with ToBRFV were used for the cleft grafting as rootstocks, and side shoot from the resistant $S$. habrochaites LA1739 plants at same age were used as scion. Rootstocks were decapitated above two basal leaves and the stems were cut vertically $1-2 \mathrm{~cm}$ deep at the center of the stem. Scions $(3-5 \mathrm{~cm})$ were prepared by removing the lower leaves and trimming the top leaves and cut the stem as wedge-shaped into the split rootstock. The rootstock and scion junction were wrapped with Parafilm. The grafted plants were covered with plastic bags to maintain humidity until the graft was complete. The presence of ToBRFV was confirmed by bioassays.

\section{DNA extraction and amplification of Solyc08g075630 gene}

Total genomic DNA were extracted from fresh leaves of a selected plant of each resistant accessions, respectively. For this purpose, ZenoGene DNA extraction kit (ZenonBio, Szeged, Hungary) was used. A 3500 bp genomic segment of the NBS-LRR gene was amplified by PCR using 
specific primers (F-5'-ATGGCTGAAGCTTTCCTTCA-3'; R-5'-GGTTACAAATAGTTGATTTGTTTCC-3') designed with Primer3 web version 4.0.0 computer software based on the sequence published by Ykema et al. (2020) which is ortholog with the sequences of $S$. lycopersicon (SOLgenomics) Solyc08g075630 loci. The PCR fragments were cloned into pGEM $^{\circledR}$-T Easy plasmid (Promega, Madison, USA) according to standard protocols and sequenced with SANGER technology on ABI Prism 3130xl Genetic Analyzer (Thermo Fisher Scientific, Witham, MA, USA). For genomic comparison we used the programs DNASTAR Seqman, Bioedit, BLASTN, BLASTP and ClustalW.

\section{Results}

\section{Resistance and susceptibility of S. habrochaites and S. peruvianum to ToBRFV}

The great majority of 173 accessions of $S$. habrochaites and S. peruvianum proved to be susceptible to ToBFRV-Tom2Jo of which all individual plants expressed systemic symptoms with disease severity indices (DSI) ranging 20-100\% (Table S1).

The symptoms were mosaic, mottling, and sometimes deformation of top leaves which started to appear 10-14 dpi, and usually became characteristic as listed in Table 1 and presented in Fig. 1. Control tomatoes, i.e., GCR26Craigella $\left(\right.$ tm- $\left.1^{\mathrm{GCR} 26}\right)$, GCR237-LA3269 (Tm-1), LA2088 $(T m-2)$, LA3471-Moneymaker $\left(T m-2^{2}\right)$ and Ceglédi $(T m+)$ became also infected, showing severe viral symptoms (data not shown).

Symptomatological observations revealed that following three inoculations with ToBRFV, a number of plants in nine accessions of $S$. habrochaites (LA1738, LA1739, LA2171, LA2541, LA 2812, PI 308,182, PI 379,012, PI 379,014 and PI 390,659) and one of $S$. peruvianum (PI 308,181 ) remained symptomless both locally and systemically after $40 \mathrm{dpi}$ (Table S1). The presence of asymptomatic and symptomatic individuals at different frequencies (2-10 resistant plant out of 15 inoculated) clearly showed that these accessions segregated for the type of reactions to the virus (Fig. 2). No symptoms were also detected in the cuttings that originated from rooted shoots of the symptomless plants after inoculation with TMV and ToMV after $40 \mathrm{dpi}$ (data not shown).

Inoculating Nicotiana glutinosa local lesion test plants, no virus could be detected in either the inoculated or in the top leaves of symptomless resistant plants (Fig. 3a, left side). On the contrary, a great number of necrotic local lesions appeared on leaves of $N$. glutinosa inoculated with the extract of symptomatic plants, including the susceptible $S$. lycopersicum controls (Fig. 3a, right side). Using RT-qPCR, no virus was demonstrated in the inoculated and top leaves of plants evaluated resistant to ToBRFV by symptoms and biotests (Fig. 4a, b). At the same time, a high concentration of viral nucleic acid was detected in the inoculated and top leaves of the symptomatic $S$. lycopersicum controls. Furthermore, the expression levels of the internal control genes of all samples were detected and shown in (Fig. 5). Exactly the same results were obtained when young cuttings of ToBRFV resistant plants were assayed with TMV and ToMV, no symptoms were observed and no viruses were demonstrated in the inoculated plants by biotests using $N$. glutinosa and RT-qPCR (data not shown).

\section{Reactions of resistant wild tomato plants to ToBRFV under elevated temperature}

The resistant $S$. habrochaites and $S$. peruvianum plants became severely affected by ToBRFV-Tom2-Jo at $33{ }^{\circ} \mathrm{C}$ showing mosaic, leaf deformation and stunting (Fig. 6a). ToBRFV was detected in their symptomatic top leaves by bioassays and RT-qPCR (Figs. 7, 8a). In contrast, the inoculated sister plants grown in a greenhouse at $24{ }^{\circ} \mathrm{C}$ were symptomless and virus-free as assessed by bioassay and RT-qPCR (Figs. 6a, 8a). The resistant plants that expressed severe symptoms at $33{ }^{\circ} \mathrm{C}$ developed symptomless new leaves after being kept in the greenhouse at $24{ }^{\circ} \mathrm{C}$ (Fig. 6b). Surprisingly, these newly developed leaves were also free from the virus, as established by bioassay or RTqPCR (Fig. 8a).

\section{Infection of plants following grafting}

Five repetitions of cleft grafting using scions of only one accession of plants resistant $S$. habrochaites LA1739 plants were successful, but other accessions plants not yet done (Fig. 9a). The scions started to show mosaic symptoms on the top leaves 30 days after grafting, and their newly developed leaves also became symptomatic (Fig. 9b). The virus was detected in the diseased leaves of the scions by bioassays using $N$. glutinosa (data not shown).

\section{Molecular data analysis}

To our knowledge Ykema et al. (2020) described a gene in S. habrochaites (LYC4943) responsible for resistance against ToBRFV. Analysing the sequence published by Ykema et al. (2020) we identified the S. lycopersicum gene Solyc08g075630 (Solgenomics) using BLASTP. We compared the protein sequences of our resistant accessions (LA1738, LA1739, LA2171, LA2541, LA 2812, PI 308,181, PI 308,182, PI 379,012, PI 379,014 and PI 390,659), with those of Solyc08g075630 locus and the data of Ykema et al. (2020). 

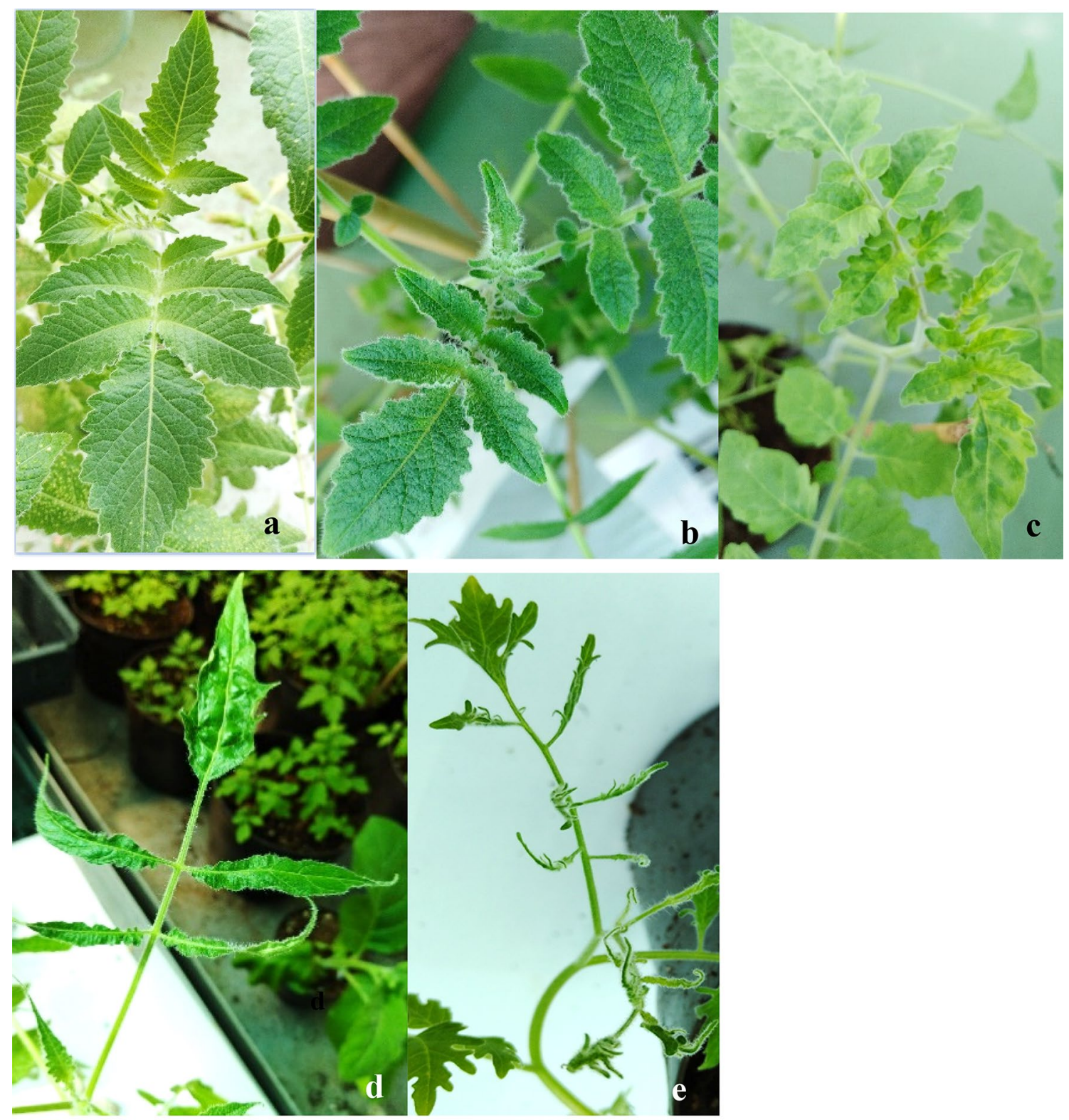

Fig. 1 Solanum habrochaites $(\mathbf{a}, \mathbf{b}, \mathbf{d})$ and S. peruvianum (c, e) plants susceptible to ToBRFV demonstrating the classes of typical disease symptoms; $\mathrm{a}=$ no symptoms, $\mathrm{b}=$ mild mosaic, $\mathrm{c}=$ mosaic, $\mathrm{d}=$ mosaic and leaf deformations, $\mathrm{e}=$ mosaic, leaf deformation and shoestring

Eight resistant plants selected from different accessions of $S$. habrochaites and one resistant plant of S. peruvianum showed high heterogeneity. Only one resistant plant originated from $S$. habrochaites LA2812 was found to carry an allele almost identical $(99.90 \%)$ to the resistance gene identified in $S$. habrochaites LYC4943 by Ykema et al. (2020). S. habrochaites LA2812 differed from LYC4943 in one nucleotide substitution resulting in a single amino acid (AA) change in the Solyc08g075630 gene. However, other sequences (PI 379,012, PI 308,181, LA1738 and PI $379,014)$ showed lower similarities $(80-88 \%)$ compared to the resistance gene, respectively. In addition, five accessions
PI 390,659, PI 308,182, LA1739, LA2171, LA2541 contained a truncated or putative version of the NBS LRR gene (Fig. S1).

\section{Discussion}

Breeding and producing resistant cultivars is the most powerful way to control virus diseases of tomatoes including those caused by tobamoviruses (Kole 2011). Three tobamovirus resistance genes marked $T m-1, T m-2$ and $T m-2^{2}$ have been incorporated into cultivated tomatoes from wild tomato 


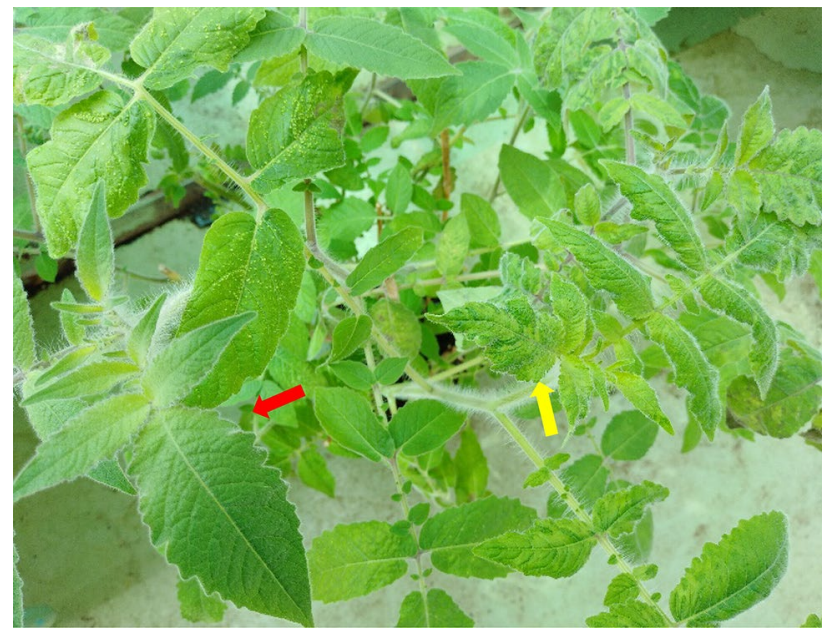

Fig. 2 The Solanum habrochaites accession PI 379,012 segregate for resistant (symptomless, red arrow) and susceptible (showing mosaic, yellow arrow) individuals after repeated inoculation with ToBRFV

species S. habrochaites and S. peruvianum (Alexander 1963; Soost 1963). Each of them has been demonstrated to break down by specific mutants of tobacco mosaic or tomato mosaic viruses (Betti et al. 1997; Calder and Palukaitis 1992; Meshi et al. 1989). Overcoming the most durable Tm$2^{2}$ allele by ToBRFV (Salem et al. 2016) draws the attention of virologists and breeders to search for new tobamovirus resistance sources. Recently, several authors reported resistance to ToBRFV in some genotypes of $S$. lycopersicum, $S$. pimpinellifolium, S. habrochaites and S. ochrantum (Ashkenazi et al. 2020; Hamelink et al. 2019; Jewehan et al. 2021; Ykema et al. 2020). Besides them, tolerance has been found in S. lycopersicum and in wild tomato plants (Ashkenazi et al. 2018).

Our previous studies demonstrated only susceptible and tolerant (symptomless, virus infected) plants in 636 accessions of 16 Solanum species (Jewehan et al. 2021). In the present work, 163 accessions of $S$. habrochaites and S. peruvianum were detected susceptible to ToBRFV. However, we also found nine accessions of $S$. habrochaites and one accession of $S$. peruvianum segregated in resistant and susceptible plants (Table S1).

The resistant individuals have been easily detected because they could not show systemic symptoms after inoculation with ToBRFV, grow healthy, and ToBRFV could not be detected in their inoculated and newly-developed leaves.

Fig. 3 No symptoms (left side) and necrotic local lesions (right side) on Nicotiana glutinosa assay plants inoculated with the extract of top leaf of ToBRFV resistant Solanum habrochaites (LA1739) and with extract of ToBRFV infected $S$. lycopersicum positive control, respectively (a). Local lesions caused by ToMV (b) and TMV (c) transmitted from of infected leaves of S. lycopersicum positive control
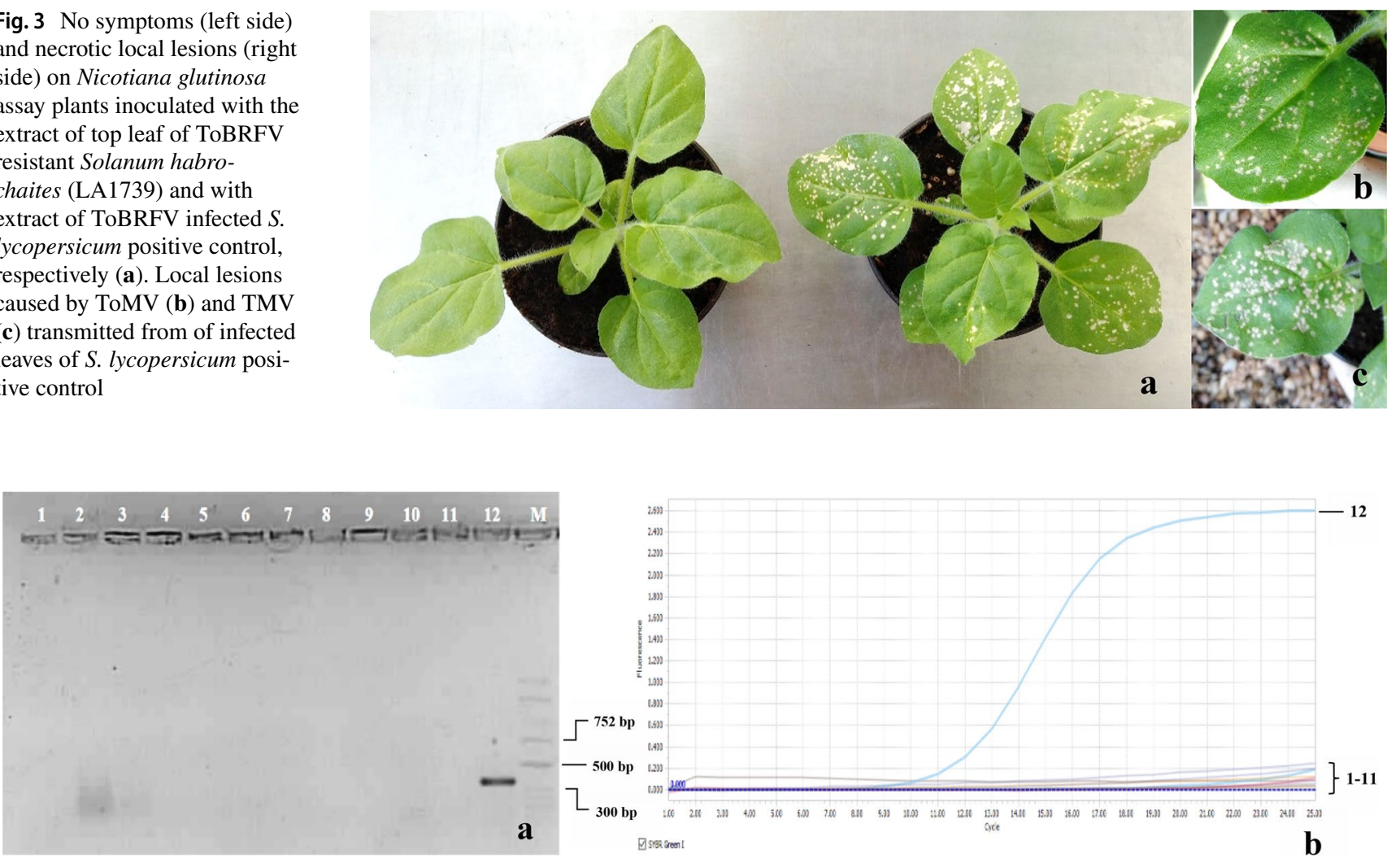

Fig. 4 Electrophoretic detection of PCR product of resistant (2-11) and susceptible (12) tomatoes infected with ToBRFV (a). Amplification curves of PCR products using RT-qPCR (b). M=Molecular marker; Numbering of accessions: $1=$ Negative control; $2=\mathrm{LA} 1738$;
$3=\mathrm{LA} 1739 ; 4=\mathrm{LA} 2171 ; 5=\mathrm{LA} 2541 ; 6=\mathrm{LA} 2812 ; 7=\mathrm{PI} 308,182 ;$ $8=$ PI 379,$012 ; 9=$ PI 379,$014 ; 10=$ PI 390,$659 ; 11=$ PI 308,181 ; $12=$ positive control. The expected PCR product size was 350 base pair (bp) 


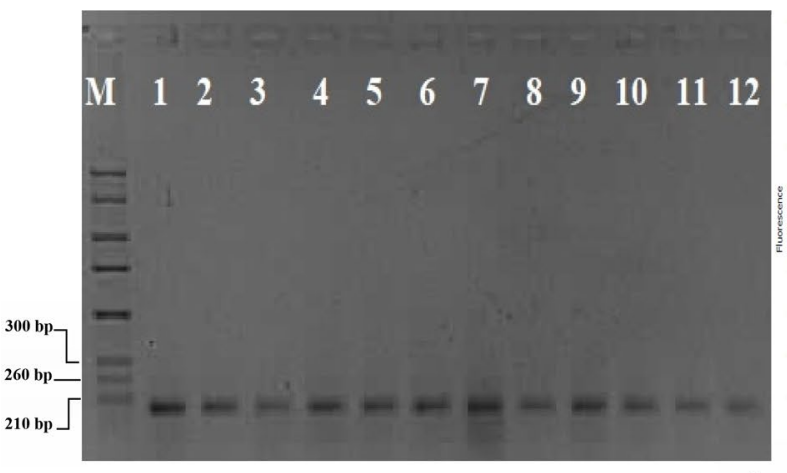

a

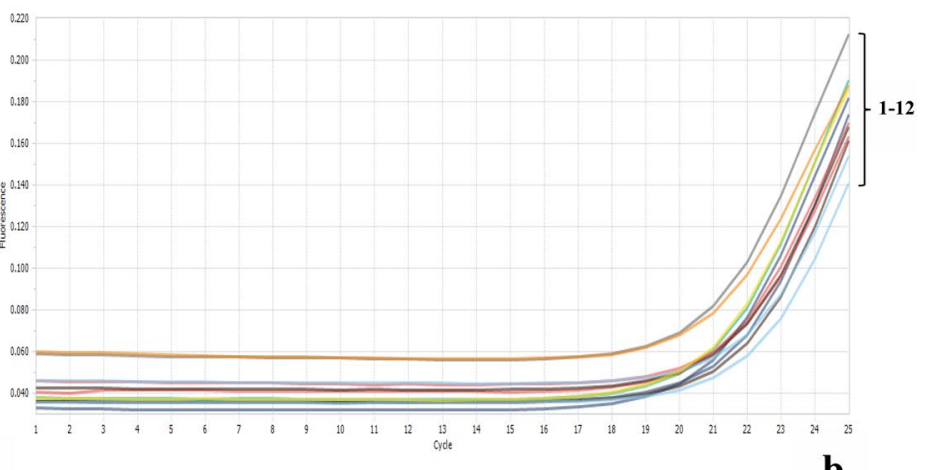

b

Fig. 5 Electrophoretic detection of PCR product of internal control gene (GAPDH) of resistant and susceptible samples (a). Amplification curves of PCR products using RT-qPCR (b). $\mathrm{M}=$ Molecular marker; Numbering of accessions: $1=$ Negative control; $2=\mathrm{LA} 1738$;

$3=\mathrm{LA} 1739 ; 4=\mathrm{LA} 2171 ; 5=\mathrm{LA} 2541 ; 6=\mathrm{LA} 2812 ; 7=$ PI 308,182; $8=$ PI 379,012; $9=$ PI 379,014; $10=$ PI 390,659; $11=$ PI 308,181; $12=$ positive control. The expected PCR product size was 200 base pair (bp)
Fig. 6 The effect of temperature on the development of symptoms on resistant Solanum habrochaites PI 390,659 inoculated with ToBRFVTom2-Jo. The plant remained symptomless and virus free at $24{ }^{\circ} \mathrm{C}$ (left) but showed mosaic, deformation and stunting and contained virus at $33{ }^{\circ} \mathrm{C}$ after 15-20 dpi (right) (a). Recovery of resistant plants three weeks after transfer from $33^{\circ} \mathrm{C}$ to the greenhouse $24^{\circ} \mathrm{C}$. Symptomatic leaves (red arrow) and recovered leaves (blue arrow) on the same plant (b)
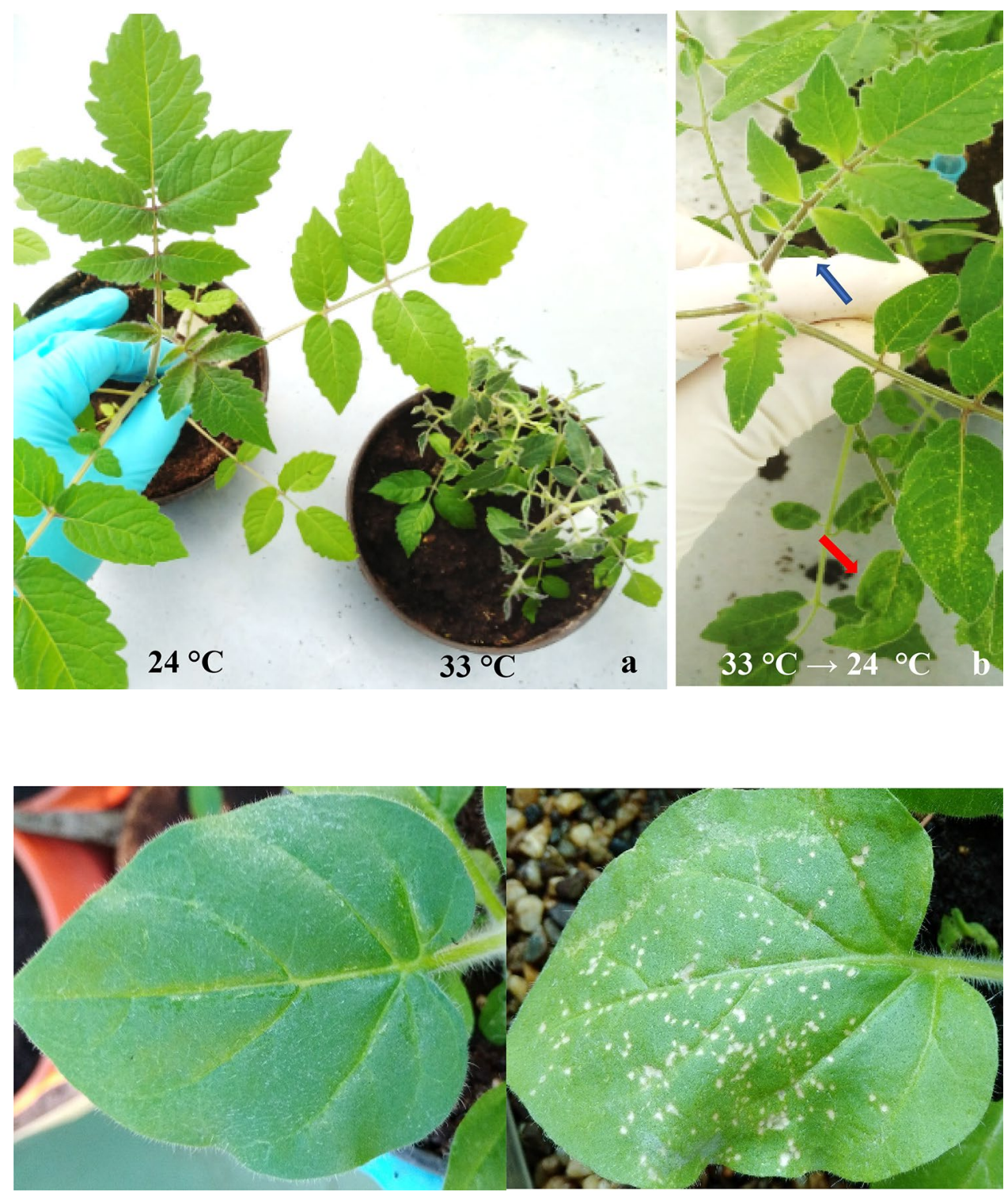

Fig. 7 No symptoms (left side) and necrotic local lesions (right side) on Nicotiana glutinosa assay plant inoculated with the extract of top leaf of ToBRFV resistant Solanum habrochaites PI 390,659 and with extract of ToBRFV infected S. lycopersicum positive control, respectively at $33{ }^{\circ} \mathrm{C}$ 

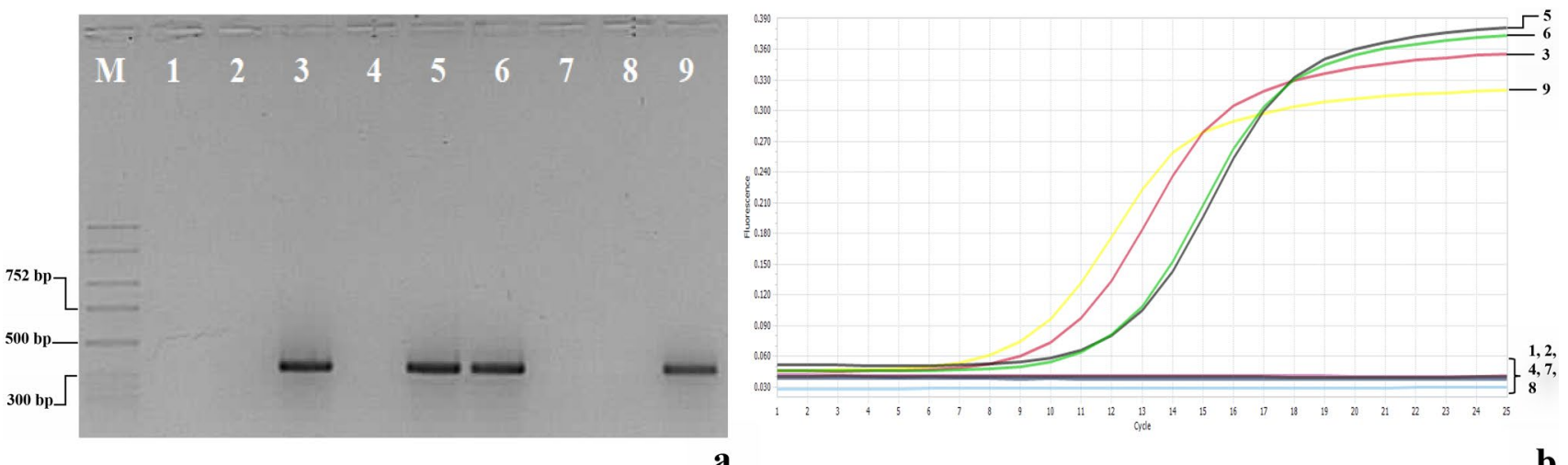

Fig. 8 Electrophoretic detection of PCR product of effect of temperature on the development of symptoms on resistant Solanum habrochaites PI 390,659 inoculated with ToBRFV-Tom2-Jo (a). Amplification curves of PCR products using RT-qPCR (b). M=Molecular marker, at $24{ }^{\circ} \mathrm{C}: 1=$ Negative control; $2=$ Sample extracted top leaf;
$3=$ positive control, at $33{ }^{\circ} \mathrm{C}: 4=$ Negative control; $5=$ Sample extracted top leaf; $6=$ positive control, Recovery of resistant plants (at $24{ }^{\circ} \mathrm{C}$ ): $7=$ Negative control; $8=$ Sample extracted top leaf; $9=$ positive control. The expected PCR product size was 350 base pair (bp)
Fig. 9 Cleft grafting was successful and the plant started to grow 15 days after grafting (a), mosaic symptoms (yellow arrow) expressed in resistant scion 30 days after grafting (b)

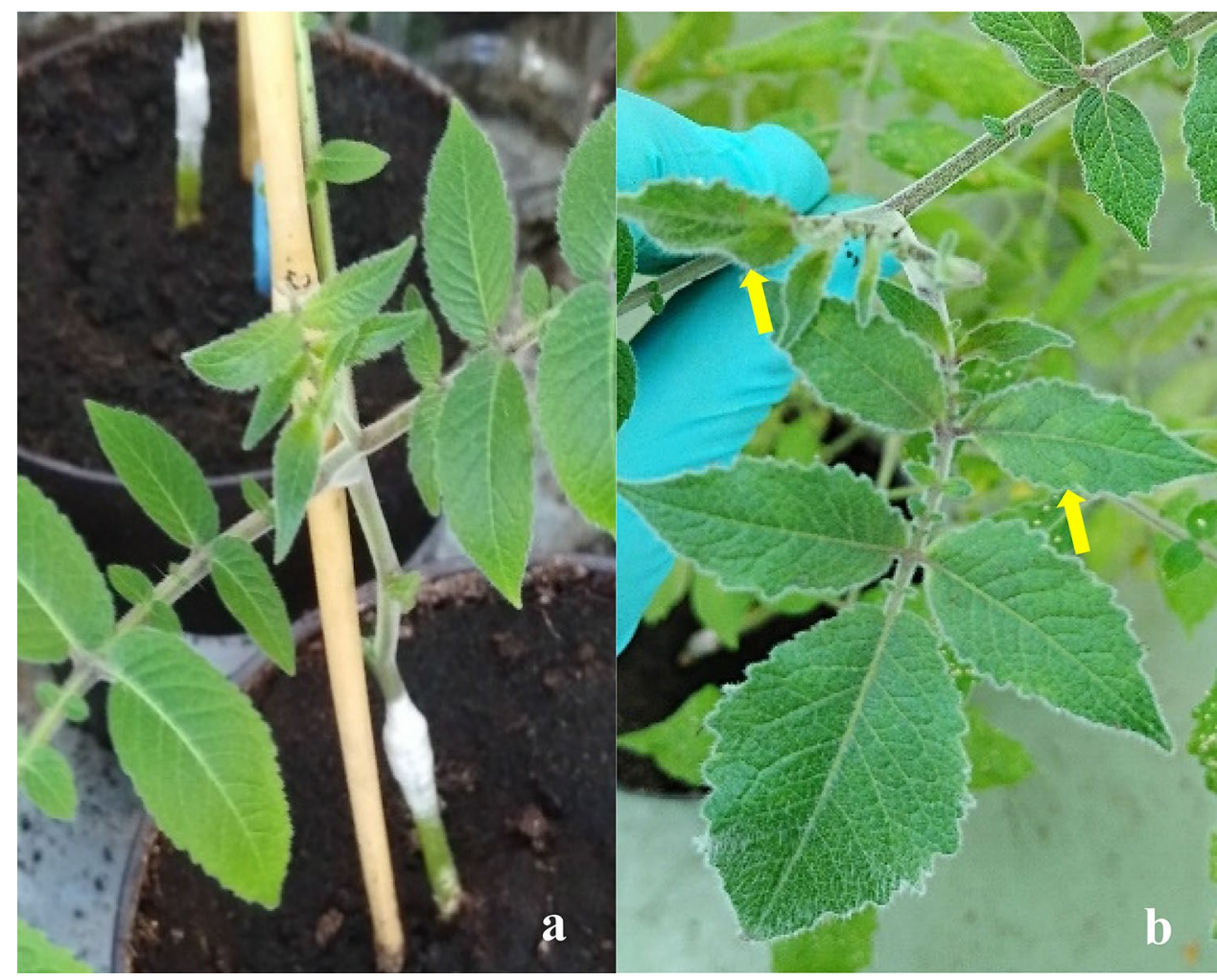

We expected that similar resistance has been found by Ykema et al. (2020) in S. habrochaites. However, the reactions of $S$. peruvianum PI 308,181 to ToBRFV were not yet studied, so this is the first record of ToBRFV resistance in this wild tomato species. S. habrochaites and S. peruvianum plants resistant to ToBRFV also proved highly resistant to TMV and ToMV, suggesting that the resistance covers a wide range of tomato pathogenic tobamoviruses. Our results strengthened the GRIN Plant Germplasm data (https://npgsw eb.ars-grin.gov/gringlobal/descriptordetail?id=50145), on the resistance of numerous wild tomato accessions to TMV. In addition, we also demonstrated TMV resistance in $S$. habrochaites accessions PI 308,182, PI 379,012, PI 379,014 , PI 390,658 (=LA1739), PI 390,659. It would be interesting to investigate the responses of these resistant plants to the Ohio V strain of TMV, tomato mottle mosaic virus (ToMMV), or the resistance breaking mutants of TMV and ToMV. 
Ashkenazi et al. (2020) reported that the $T m$ - 1 gene, in combination with QTL2 on chromosome 9 or QTL3 on chromosome 11, provides the best resistance to ToBRFV. Zinger et al. (2021) also speculated that the Tm-1 locus on chromosome 2 , interacted with the locus discovered on chromosome 11 are responsible for symptom reduction and resistance. We cannot compare the molecular similarities of our resistant plants with those used by the above authors. However, we were able to take molecular comparison with the S. habrochaites genotype LYC4943 characterized by Ykema et al. (2020). Our results proved the $S$. lycopersicum gene Solyc08g075630 as the ortholog locus (identity 90\%) to the resistance gene against ToBRFV. Besides of S. habrochaites LA2812, which was very similar to those characterized by Ykema et al. (2020), other resistant plants in our experiments showed high sequence variability on the NBS LRR locus. Therefore, it could not be exclude, that $S$. habrochaites and $S$. peruvianum accessions may carry more than a single new resistance gene to ToBRFV.

Regarding the mechanism of resistance found in S. habrochaites and $S$. peruvianum, it is important to point out that we could detect ToBRFV neither locally nor systemically following repeated mechanical inoculations of resistant plants. Even so, we assume that the virus starts to replicate in some locally infected cells of resistant plants and at elevated temperatures, ToBRFV causes systemic and severe disease on them. High inhibition capacity of virus replication and/or cell to cell movement can be presumed as a cause of resistance. This resistance also could be characterized by overcome at $33{ }^{\circ} \mathrm{C}$, but restore in function at $24{ }^{\circ} \mathrm{C}$ because after moving the plants from 33 to $24^{\circ} \mathrm{C}$ the newly developed leaves recovered from the symptoms and the virus itself. Temperature-dependent virus multiplication was also reported by Cirulli and Ciccarese (1975) and Fraser and Loughlin (1982). Loss of resistance to ToBRFV in a line LA1739 of $S$. habrochaites was also demonstrated by grafting onto the infected susceptible rootstock (S. lycopersicum cv. Ceglédi).

The type of resistance is still unknown. The immunity can be excluded because the resistant plants became infected at elevated temperatures and after grafting to infected rootstock. It is important to note that, we recently identified a mutant of ToBRFV that break the resistance found in $S$. habrochaites and $S$. peruvianum. This mutant differed solely in the movement protein (MP) from the parent virus (unpublished data). These results strongly suggest that the resistance is an active process and the MP elicits a resistance gene similar to TMV and ToMV in tomatoes harbouring the $T m-2^{2}$ gene (Pfitzner 2006). We cannot exclude that a strong gene silencing mechanism also plays a role in inhibiting virus replication and/or movement in the resistant plants (Bucher and Prins 2006).
The present study concluded that ten accessions of $S$. habrochaites and $S$. peruvianum carry a rich repository of ToBRFV resistance which were not reported before and therefore, they are new resistance sources of this virus.

Supplementary Information The online version contains supplementary material available at https://doi.org/10.1007/s10327-022-01055-8.

Acknowledgements The authors would like to thank Lilla Hajnik for her help in molecular analysis.

Funding Open access funding provided by Hungarian University of Agriculture and Life Sciences. This study was supported by the Stipendium Hungaricum scholarship program supervised by the Ministry of Foreign Affairs and Trade of Hungary and managed by the Tempus Public Foundation.

Availability of data and material The data that support the findings of this study are available from the corresponding author upon reasonable request.

Code availability Not applicable.

\section{Declarations}

Conflict of interest The authors declare no conflict of interest.

Ethics approval Not applicable

Consent to participate Not applicable.

Consent for publication The authors have consented to the publication of the current version of the article.

Ethical approval This article does not contain any studies with human participants or animals performed by any of the authors.

Open Access This article is licensed under a Creative Commons Attribution 4.0 International License, which permits use, sharing, adaptation, distribution and reproduction in any medium or format, as long as you give appropriate credit to the original author(s) and the source, provide a link to the Creative Commons licence, and indicate if changes were made. The images or other third party material in this article are included in the article's Creative Commons licence, unless indicated otherwise in a credit line to the material. If material is not included in the article's Creative Commons licence and your intended use is not permitted by statutory regulation or exceeds the permitted use, you will need to obtain permission directly from the copyright holder. To view a copy of this licence, visit http://creativecommons.org/licenses/by/4.0/.

\section{References}

Adams MJ, Antoniw JF, Kreuze J (2009) Virgaviridae: a new family of rod-shaped plant viruses. Arch Virol 154:1967-1972

Alexander LJ (1963) Transfer of a dominant type of resistance to 4 known Ohio pathogenic strains of tobacco mosaic virus (TMV), from Lycopersicon Peruvianum to Lycopersicon esculentum. Phytopathology 53:869 
Ashkenazi V, Rotem Y, Ecker R, Nashilevitz S, Barom N (2018) Tolerance in plants of Solanum lycopersicum to the tobamovirus tomato brown rugose fruit virus (TBRFV). Patentscope. p 38. https:// patentscope.wipo.int/search/en/detail.jsf?docId=WO2018219941

Ashkenazi V, Rotem Y, Ecker R, Nashilevitz S, Barom N (2020) Resistance in plants of Solanum lycopersicum to the tobamovirus tomato brown rugose fruit virus. Patentscope. p 60. https://patentscope. wipo.int/search/en/detail.jsf?docId=WO2020249798\& tab= SEARCHREPORT

Betti L, Marini F, Marani F, Cuffiani M, Rabiti AL, Canova A (1997) A TMV strain overcoming both $T m-2$ and $T m-2^{2}$ resistance genes in tomato. Phytopathol Mediterr 36:24-30

Bucher E, Prins M (2006) RNA silencing: a natural resistance mechanism in plants. Natural resistance mechanisms of plants to viruses. Springer, Netherlands, pp 45-72

Calder VL, Palukaitis P (1992) Nucleotide sequence analysis of the movement genes of resistance breaking strains of tomato mosaic virus movement genes, encoding $30 \mathrm{~K}$ proteins, of two resistance breaking strains of tomato mosaic virus. J Gen Virol 73:165-168

Camara M, Mbaye AA, Noba K, Samb PI, Diao S, Cilas C (2013) Field screening of tomato genotypes for resistance to tomato yellow leaf curl virus (TYLCV) disease in Senegal. Crop Prot 44:59-65

Chanda B, Shamimuzzaman M, Gilliard A, Ling KS (2021) Effectiveness of disinfectants against the spread of tobamoviruses: Tomato brown rugose fruit virus and Cucumber green mottle mosaic virus. Virol J 18:1-12

Cirulli M, Ciccarese F (1975) Interactions between TMV isolates, temperature, allelic condition and combination of the Tm resistance genes in Tomato. Phytopathol Mediterr 14:100-105

Davino S, Caruso AG, Bertacca S, Barone S, Panno S (2020) Tomato brown rugose fruit virus: seed transmission rate and efficacy of different seed disinfection treatments. Plants 9:1615

Dombrovsky A, Smith E (2017) Seed transmission of tobamoviruses: aspects of global disease distribution. In: Jimenez-Lopez JC (ed) Seed biology. IntechOpen, London, pp 234-260

Expósito-Rodríguez M, Borges AA, Borges-Pérez A, Pérez JA (2008) Selection of internal control genes for quantitative real-time RTPCR studies during tomato development process. BMC Plant Biol $8: 1-12$

Fraser RSS, Loughlin SAR (1982) Effects of temperature on the Tm-1 gene for resistance to tobacco mosaic virus in tomato. Physiol Plant Pathol 20:109-117

Fraser RSS, Loughlin SAR, Connor JC (1980) Resistance to tobacco mosaic virus in tomato: effects of the $\mathrm{Tm}-1$ gene on symptom formation and multiplication of virus strain 1. J Gen Virol 50:221-224

Hamelink R, Kalisvaart J, Rashidi H (2019) TBRFV resistant tomato plant. Patentscope. p 34. https://patentscope.wipo.int/search/en/ detail.jsf?docId=WO2019110130\&tab $=$ PCTBIBLIO\&_cid $=$ P10-KPB4P1-64395-1

Holmes FO (1954) Inheritance of resistance to infection by tobaccomosaic virus in tomato. Phytopathology 44:640-642

Jewehan A, Salem N, Tóth Z, Salamon P, Szabó Z (2021) Screening of Solanum (sections Lycopersicon and Juglandifolia) germplasm for reactions to the tomato brown rugose fruit virus (ToBRFV). J Plant Dis Prot 1-7

Kole C (2011) Wild crop relatives: genomic and breeding resources: vegetables. Springer, Berlin

Laterrot H, Pecaut P (1969) Gene Tm-2: new source. Rep Tomato Genet Coop 19:13-14
Levitzky N, Smith E, Lachman O, Luria N, Mizrahi Y, Bakelman H, Sela N, Laskar O, Milrot E, Dombrovsky A (2019) The bumblebee Bombus terrestris carries a primary inoculum of tomato brown rugose fruit virus contributing to disease spread in tomatoes. PLoS ONE 14(1):e0210871

Luria N, Smith E, Reingold V, Bekelman I, Lapidot M, Levin I, Elad N, Tam Y, Sela N, Abu-Ras A, Ezra N, Haberman A, Yitzhak L, Lachman O, Dombrovsky A (2017) A new Israeli Tobamovirus isolate infects tomato plants harboring $T m-2^{2}$ resistance genes. PLoS ONE 12:1-19

Meshi T, Motoyoshi F, Maeda T, Yoshiwoka S, Watanabe H, Okada $\mathrm{Y}$ (1989) Mutations in the tobacco mosaic virus $30-\mathrm{kD}$ protein gene overcome $T m-2$ resistance in tomato. Plant Cell 1:515-522

Oladokun JO, Halabi MH, Barua P, Nath PD (2019) Tomato brown rugose fruit disease: current distribution, knowledge and future prospects. Plant Pathol 68:1579-1586

Panno S, Caruso AG, Blanco G, Davino S (2020) First report of tomato brown rugose fruit virus infecting sweet pepper in Italy. New Dis Rep 41:588-2044

Pelham J (1972) Strain-genotype interaction of tobacco mosaic virus in tomato. Ann Appl Biol 71:219-228

Pfitzner AJP (2006) Resistance to tobacco mosaic virus and tomato mosaic virus in tomato. In: Loebenstein G, Carr JP (eds) Natural resistance mechanisms of plants to viruses. Springer, Dordrecht, pp 399-413

Razdan MK, Mattoo AK (2006) Genetic improvement of solanaceous crops volume 2: Tomato. CRC Press, Boca Raton

Salem N, Mansour A, Ciuffo M, Falk BW, Turina M (2016) A new tobamovirus infecting tomato crops in Jordan. Arch Virol 161:503-506

Salem NM, Cao MJ, Odeh S, Turina M, Tahzima R (2020) First report of tobacco mild green mosaic virus and tomato brown rugose fruit virus infecting Capsicum annиum in Jordan. Plant Dis 104:601

Samarah N, Sulaiman A, Salem NM, Turina M (2021) Disinfection treatments eliminated tomato brown rugose fruit virus in tomato seeds. Eur J Plant Pathol 159:153-162

Schroeder WT, Provvidenti R, Robinson RW (1967) Incubation temperature and virus strains important in evaluating tomato genotypes for tobacco mosaic virus reactions. Tomato Genet Coop Rep 17:47-48

Soost RK (1963) Hybrid tomato resistant to tobacco mosaic virus. J Hered 54:241-244

Spanò R, Ferrara M, Gallitelli D, Mascia T (2020) The role of grafting in the resistance of tomato to viruses. Plants 9:1-20

Ykema M, Verweij CW, De La Fuente Van Bentem S (2020) Tomato plant resistant to tomato brown rugose fruit virus. Patentscope. p 143. https://patentscope.wipo.int/search/en/detail.jsf?docId= WO2020147921\&tab=PCTBIBLIO

Zinger A, Lapidot M, Harel A, Doron-Faigenboim A, Gelbart D, Levin I (2021) Identification and mapping of tomato genome loci controlling tolerance and resistance to tomato brown rugose fruit virus. Plants 10:179

Publisher's Note Springer Nature remains neutral with regard to jurisdictional claims in published maps and institutional affiliations. 